\title{
Emerging from the shadow of the Soviet Union: The case of the accountancy field in Latvia
}

DOI:

10.1108/AAAJ-08-2020-4799

\section{Document Version}

Accepted author manuscript

Link to publication record in Manchester Research Explorer

\section{Citation for published version (APA):}

Praulins, A., Spence, C., \& Voulgaris, G. (2022). Emerging from the shadow of the Soviet Union: The case of the accountancy field in Latvia. Accounting, Auditing and Accountability Journal. https://doi.org/10.1108/AAAJ-082020-4799

\section{Published in:}

Accounting, Auditing and Accountability Journal

\section{Citing this paper}

Please note that where the full-text provided on Manchester Research Explorer is the Author Accepted Manuscript or Proof version this may differ from the final Published version. If citing, it is advised that you check and use the publisher's definitive version.

\section{General rights}

Copyright and moral rights for the publications made accessible in the Research Explorer are retained by the authors and/or other copyright owners and it is a condition of accessing publications that users recognise and abide by the legal requirements associated with these rights.

\section{Takedown policy}

If you believe that this document breaches copyright please refer to the University of Manchester's Takedown Procedures [http://man.ac.uk/04Y6Bo] or contact uml.scholarlycommunications@manchester.ac.uk providing relevant details, so we can investigate your claim.

\section{OPEN ACCESS}




\title{
Emerging from the shadow of the Soviet Union: The case of the accountancy field in Latvia
}

\begin{abstract}
$\underline{\text { Abstract }}$
Purpose

This article explores the structure of the accounting field in a post-Soviet context - Latvia. The aim of the study is to generate insights into the extent to which professionalization processes are shaped by national particularities and to demonstrate how self-styled professional fields change over time.

\section{Design/methodology/approach}

Drawing from the relational sociology of Pierre Bourdieu and drawing on 83 interviews, the paper highlights the forms of capital (cultural and social primarily) that help define what constitutes appropriate conduct for successful career progression therein.
\end{abstract}

\section{Findings}

The values ascribed to forms of capital that structure the Latvian accounting field fluctuate across time and space. This suggests that the structure of professional fields - as understood by the structuring properties of different forms of capital - is variable and fluid. Additionally, fields themselves can become more or less desirable over time to those who possess certain forms of capital.

\section{Originality}

The findings are important for understanding the form that an accounting field can take in an emerging economy that has fully embraced neoliberalism while maintaining strong residues of the Soviet system. The findings are also relevant for understanding the dynamics change more broadly in self-styled professional fields.

\section{Research limitations/implications}

Although the results may be specific to one national accounting field, the idiosyncrasies constitute the contribution of the paper, showing that the form and structure of accounting fields vary in accordance with national particularities. Overall, the paper highlights the importance of fit between habitus and field and of adjustment to the surrounding rules of the game in professional contexts.

\section{Keywords}

accounting field; Bourdieu; forms of capital; Latvia; post-Soviet 


\section{Introduction}

Although the progressively global character of professional services in general (Faulconbridge and Muzio, 2012) and accounting in particular (Suddaby et al., 2007) has been recognized, still surprisingly little is known about common and distinctive features of the accountancy profession in emerging economies (Gillis et al., 2014). Scholars investigating developing nations have mainly focused on examining the emergence and early evolution of indigenous accounting associations (Annisette, 2000; Dyball et al., 2007; Sian, 2006) rather than exploring the influence of socioeconomic and political contexts different from Western countries upon the behaviour and work of modern-day accounting professionals. An exception to this trend is the studies that have compared the habitus of partners from professional service firms across Bangladesh, the UK, Canada, France and Spain (Spence et al., 2016), China and Japan (Spence et al., 2017b). Overall, however, it seems that contemporary work on the professions still predominantly exhibits the characteristics of the Western ethnocentrism described several decades ago (Johnson, 1973).

The focus of our study is on post-Soviet countries for a number of reasons. First, although these countries have attracted scholarly attention, extant research predominantly focuses on their development, regulation (see, for example, McGee, 2008; Seal et al., 1996; Solodchenko and Sucher, 2005) and contribution of the accountancy profession to the reformation of their national accounting systems (Alexander and Ghedrovici, 2013; Grabinski et al., 2014). Studies have also explored the transformation of assurance services (Mennicken, 2010) and the particularities, difficulties and response of local accounting firms to implementing international standards in specific post-Soviet contexts (Cooper et al., 1998; Mennicken, 2008; Samsonova-Taddei, 2013). While these studies have successfully emphasised the importance of local context to new accounting initiatives or changes, they have not taken as their research object the accounting field per se. As such, we believe that there is more to say about processes of professionalization in post-Soviet contexts.

Second, although the Soviet system collapsed three decades ago, the members of the former Eastern Bloc still evince specific characteristics that distinguish these countries from the developed world (Hall and Soskice, 2001; Morgan et al., 2010). The post-Soviet transition period has been marked by overall degradation of regulated employment relations (Woolfson, 2007), aggressive neo-liberal capitalism and accompanying economic recession, high unemployment, social differentiation and drop in the standard of living (Alam et al., 2005; Heyns, 2005). A high proportion of the labour force earns the minimum wage or works in the "shadow" sectors of the economy on contingent, fixed-term and false 'full-time' employment contracts, experience delayed remuneration payments, unpaid overtime and unreasonably long working hours, economic and social insecurity, and countless other violations of labour rights (Clarke, 2000; Round et al., 2008). Among new members of the EU, the Baltic States, one of them Latvia, are considered among the most neo-liberal (Woolfson, 2006) and notorious for these poor working conditions (Woolfson, 2007). We thus believe that such a unique context provides a fruitful means of exploring the ways in which professional fields come to be developed when the usual exogenous structuring principles provided by both the state and the market are not present in the same way.

Using the conceptual framework developed by French sociologist Pierre Bourdieu (Bourdieu and Wacquant, 1992), we conduct a critical analysis of the professional accounting field in Latvia by exploring the different values accorded to different forms of capital therein by its participants. This gives us an opportunity to study and realize the influence of the post-Soviet context on the accountancy profession and careers pursued by professionals therein. Specifically, we aim to explore the following research question: what different forms of capital are valued in the Latvian accountancy field by various factions of the accountancy profession? In answering this question, we both empirically elucidate the dynamics pertaining to the Latvian accountancy field and make three conceptual contributions: firstly, we illustrate how different sections of the field privilege certain forms of capital over others, highlighting field heterogeneity and spatial differentiation; secondly, we show how forms of capital come to have different values attached to them over time, highlighting a temporal dimension to professional field structure; finally, we highlight not only how different forms of capital fluctuate in value across time and space but how a field itself can become less desirable to certain holders of capital, prompting them to seek entry to adjacent or different fields entirely. 
The structure of the paper is as follows. The next section contains the theoretically structured literature review that integrates the main postulates of Bourdieu's framework with studies examining the importance and major roles played by different forms of capital in the accounting field in various countries. It is followed by an outline of methods employed for data collection and analysis. The empirical findings are then presented before proceeding to a discussion of the findings and suggestions for future research.

\section{A review of previous studies 2.1. Capitals, social field and habitus}

Dobbin (2008) describes Pierre Bourdieu's framework as a synthesis of theories of social structure (the field), power relations (different forms of capital) and the individual (habitus). In order to enter and move within a field, agents need resources known as capital. The most renowned types of capital identified by Bourdieu (1986) are economic, social, cultural and symbolic. Despite mutual convertibility, capital "liquidity" and exposure to loss due to attrition and inflation levels are different. Economic capital, whose main source is agent's revenues, is most liquid and can be easily not only converted into any other type of capital but also immediately and directly transformed into money or institutionalized in property rights (Bourdieu, 1986). As social capital is "stickier", less liquid and suffers from attrition, its convertibility into economic capital is a more dependent and expensive process with much lower "exchange rate". Whereas the convertibility of social capital into cultural capital is also problematic, the reverse process is fairly straightforward (Anheier et al., 1995). Commonly, agents tend to discredit "the form of capital upon which the force of their opponents rests [..] and to valorise the species of capital they preferentially possess" (Bourdieu and Wacquant, 1992, p.99). Cultural capital is obtained from the family or educational institutions primarily and predominantly credited with determining agent's status and position in the field. There are institutionalized, embodied and objectified forms of cultural capital (Bourdieu, 1986).

A social field is a "set of objective, historical relations between positions anchored in certain forms of power (or capital)" (Bourdieu and Wacquant, 1992, p.16). Any intricate society consists of various social fields that constitute social spaces where the interaction of social agents and institutions occurs in accordance with certain rules, which are generally not formal but unspoken (Bourdieu, 1977). Due to specific rules and stakes, the achievements in one field are not automatically recognized and rewarded in others. In addition to being an "entry ticket" to a field, a certain combination of various types of capital possessed by an agent, particularly, economic and cultural capital, states an agent's position in the field and social space in relevance to the positions of other agents. A social field is a "locus of struggles" between agents for their positions and the maximization of the amount of possessed capital (Bourdieu and Wacquant, 1992).

Habitus is "the strategy generating principle enabling agents to cope with unforeseen and everchanging situations" (Bourdieu, 1977, p.72) in such a manner that they act "intentionally without intention" (Bourdieu, 1990, p.12). Habitus facilitates the interaction between structure (the rules of the game) and agency (playing). Agent's position influences their language, lifestyle, tastes and preferences and consequently contributes to habitus that is obtained through primary and secondary socialization. While the former is provided by family in childhood and results in a relatively stable class habitus, the latter is based on the primary one and is obtained through formal education at school and university but later reinforced and reshaped by life experience (Bourdieu, 1977). As habitus is inertial and "durable, but not eternal" (Bourdieu and Wacquant, 1992, p.133), it cannot dynamically adjust to rapidly changing social field settings and causes the hysteresis effect (Bourdieu, 1977, 1984) - a gap between an agent's subjective expectations and objective structures.

While, following Malsch et al. (2011) we seek to apply these concepts in concert rather than piecemeal, for the sake of brevity we privilege the analysis of capitals primarily, with habitus and field being used to supplement our analysis where appropriate. We do not dedicate a separate section below to economic capital. This is not because economic capital is any less important - indeed, many other species of capital are exchanged ultimately for economic rewards - but merely because this is generally more straightforward and requires less theorization than other species of capital (Bourdieu, 1986). 


\subsection{Institutionalised cultural capital}

The institutionalised form of cultural capital contains evidence of an agent's cultural competence, e.g., academic qualifications (certificates and diplomas). Credentials help structure the contemporary social order by assigning agents to different positions and justifying unavoidable differences between them as the outcome of the talent, endeavours and aspirations (Wacquant, 1996). The importance of university degrees to pursuing a successful accounting career varies across countries. While degrees from super-elite (top four) US universities play the key role in graduates' hiring process organized by elite employers such as investment banks or consulting firms (Rivera, 2011), in France graduation from a small group of exclusive educational institutions - predominantly Parisian grandes écoles or other high-ranking foreign universities - is a precondition for becoming a member of the French business elite (Maclean et al., 2015). Due to strict selection criteria applied by grandes écoles, these degrees testify to graduates' traits such as leadership, analytical mind, overall intelligence and belonging to exclusive "old-boy network" of alumni. As in Germany there is no equivalent of French grandes écoles, alma mater is of secondary importance and the main factors in recruiting top managers are skills and personality traits required for specific positions (Hartmann, 2000). In Japan, the Big 4 firms only hire the holders of a CPA certificate. Therefore, most students who plan to pursue a career with these audit firms have to attend "cram school". As the "art of cramming" improves chances of entering elite educational institutions, CPAs predominantly are graduates of top Japanese universities (Spence et al., 2017b). The importance of the institutionalized cultural capital might vary not only at different points of career but also across countries. While in the Big 4 firms in Canada, France and the UK a professional qualification loses its initial value once it has been obtained, in Bangladesh and Japan professional credentials remain significant throughout an agent's career (Spence et al., 2016, 2017b).

Generally, it has been shown that homologies between an employer's and an applicant's experience positively impacts on the evaluation of applicant's skills because evaluators see them through the prism of their personal experience. However, the availability of disparaging information, e.g., about education quality, might result in negative influence. Typically, employers can better appreciate value of educational background analogous with their own (Rivera, 2011, 2012).

Findings of studies into postgraduate degrees as facilitators of career progression in audit firms and industry are contradictory. The analysis (Sturges et al., 2003) of MBA alumni from a top Canadian business school in Toronto shows that a master's degree can increase graduates' self-confidence and become incorporated cultural capital. Research on career trajectories in the Big 4 firms (and their predecessors) in the US reveals that postgraduate degree holders quicker become audit partners (Bhamornsiri and Guinn, 1991) but a gain in time on average is only six months (Guinn et al., 2004) and different types of master's degrees facilitate promotion at different stages of career (Brink et al., 2016). However, a study on CPAs residing in California (US) reports that university education higher than bachelor's degree does not increase the chance of becoming an audit manager (Anandarajan et al., 2002). In US industry, accounting undergraduates are in demand whereas a postgraduate degree is a characteristic of applicants for senior management positions such as controllers and financial vice-presidents (Johnson and Johnson, 1995). In the Romanian accounting labour market, in contrast, only six advertisements mentioned a master's degree as an advantage compared with all 100 job advertisements in the sample that demanded a bachelor's degree, of which 78 - in Accounting or Finance. While designations such as ACCA or CIMA are perceived as an indication of professional excellence and are a prerequisite of taking a managerial position in multinational companies, Romanian national qualifications do not represent this kind of value (Albu et al., 2011). In Poland, previous relevant work experience, a university degree (predominantly in accounting, finance or economics), knowledge of IT and foreign languages topped the list of essential requirements in job advertisements for management accounting specialists. However, employers did not specify whether a bachelor's or master's degree was expected (Zarzycka, 2017).

Although $41 \%$ of the surveyed certified accountants strongly agreed and $32 \%$ partially agreed that a certificate issued by the Association of Estonian Accountants did not give them an advantage in the labour market, $64 \%$ believed that situation might change in the future (Kallaste and Alver, 2017). In contrast, in the Czech Republic the qualification offered by the Chamber of Tax Advisors was popular with employees of the (then) Big 6. While a national certificate in accounting per se was not in great demand and 
international audit firms asked their staff to study for ACCA, its holders were eligible for sitting professional exams and joining a statutory regulated auditing profession. Unlike a degree in accounting, graduates in business, economics or law had better prospects of taking management positions in companies (Seal et al., 1996). In short, while educational and professional credentials are clearly a marker for job suitability, the value attached to this specific form of cultural capital does vary to some extent across borders.

\subsection{Embodied cultural capital}

The embodied form is manifested by long-lasting dispositions of the mind and body and presumes an onerous inculcation (Bourdieu, 1986). Traditionally, in the accountancy field soft skills are ranked as more important for promotion into senior positions than theoretical, technical knowledge or undergraduate degrees in accounting (Ahadiat and Martin, 2016). "City workers", including accountants, internalise the expectations and support their claims to "acting in a professional manner" through body-related practices such as wearing certain clothes, having firm handshakes, maintaining eye contact and knowing when and when not to speak (Anderson-Gough et al., 2005; Grey, 1998). Due to long working hours, colleagues are expected to be not only competent specialists but also culturally compatible in order to make what is an emotionally and intellectually demanding job more pleasant (Haynes, 2012). Therefore, elite professional service firms are "first and foremost looking for cultural compatibility", in other words, "cultural fit or perceived similarity to a firm's existing employee" (Rivera, 2012, pp.1006-1007) in terms of cultural background, typical extracurricular interests and self-presentation styles.

Accountants working in the post-Soviet environment have individual peculiarities. For example, in Poland, one quarter of surveyed accountants show the distinguishing personality traits of homo sovieticus (Tobór-Osadnik et al., 2013), a term coined by Russian sociologist A. Zinoviev (Zinoviev and Janson, 1982) to denote the type of personality whose thinking and behaviour has been profoundly influenced by a totalitarian system such as communism. They avoid taking any risk or responsibility for their own actions, lack creativity and critical thinking, poorly adapt to the changing environment, oppose novelty, prefer strict adherence to instructions and submission to the team or institution instead of making decisions themselves. Similarly, in Romania, most accountants are reluctant to participate in the decision-making processes and view it as managers' exclusive right and competence (Almăşan and Grosu, 2008; Grosu et al., 2014) whereas in Russia employees traditionally are accustomed to a high degree of certainty, specific means of accomplishing detailed objectives and their clear communication to the lowest level of organizational hierarchy (Michailova, 1993). The archetype of homo sovieticus is birthed in an environment which discourages individual independence of opinion and professional autonomy, destroys faith in judicial institutions, promotes widespread corruption and the practice of blat (the giving of favours) and privileges informal networks (Shlapentokh, 1996; Ledeneva, 1998; Sucher and Bychkova, 2001). These hangovers from soviet times constitute particular institutional settings that shape and determine what kind of embodied cultural capital successful auditors might need to possess.

Traditional careers in mid-sized and large audit firms including the Big 4 can be portrayed as a sequential metamorphosis from newcomers-generalists into managers-specialists and then into partnersgeneralists (Baysden, 2014). While the importance of technical competence diminishes at higher levels of professional hierarchy, the role played by soft skills such as leadership, communication, interpersonal relationship and practice development becomes more crucial in promotion to a partner position (Bhamornsiri and Guinn, 1991; Margheim et al., 2010).

As over the last decades effective selling has become an integral part of public accounting practices, nowadays commercialism is a common and important element of auditors' habitus (Spence and Carter, 2014; Spence et al., 2016). Professional service firms' partners are depicted as entrepreneurially minded agents (Sikka, 2008) who "run their micro-business within the larger [accounting] firm" (Kornberger et al., 2011, p.516). Consequently, their autonomy is limited by intense pressure to develop breakthrough ideas and raise firm revenues.

Scholars (Spence and Carter, 2014; Spence et al., 2017b) show that "technical knowledge" (embodied cultural capital) is only one of the integral elements of the Big 4 firm's partner habitus. Combination of social capital (good relations with clients) and habitus (feel for the game) helps identify client's needs precisely and convince them to buy higher value added services in addition to basic audit (Anderson-Gough 
et al., 2006; Baysden, 2014). As a result, this combination is transformed into the most appreciated form of capital in the Big 4 context - economic.

Japan constitutes a notable exception to this valorisation of economic capital because obligatory rotation of auditors takes the form of internal rotation of audit teams within the same audit firm and, consequently, "winning" new clients is well-nigh impossible task. In addition, one of the partner's main tasks such as maintaining good relationships with auditees means providing competent and high-quality services rather than persuading clients to buy additional high value-added services. As a result, business development skills are not prioritised (Spence et al., 2017b).

\subsection{Social capital}

For Bourdieu, social capital is

The aggregate of the actual or potential resources which are linked to possession of a durable network or more or less institutionalized relationships of mutual acquaintance and recognition - or in other words, to membership in a group - which provides each of its members with the backing of the collectivity-owned capital, a "credential" [..] (Bourdieu, 1986, p.51)

Adler and Kwon (2002, p.17) emphasize the intangibility of social capital and define it as "the goodwill that is engendered by the fabric of social relations and that can be mobilized to facilitate action". Different agents make different gains from the same amount of economic and cultural capital depending on their ability to mobilise social relations such as family, alumni of top-ranked university, nobility or exclusive club and their "multiplier effect" (Bourdieu, 1986, p.51). Social relations require regular renewal and reconfirmation as their efficiency tends to decrease.

Social capital is of paramount importance in the Big 4 firms where both young professionals and managers attempt to curry favour with powerful partners. Marketing oneself (Mueller et al., 2011), "blowing one's own trumpet" (Anderson-Gough et al., 2005, p.481) and "selling oneself" (Kornberger et al., 2011, p.528) significantly improve the chances of being known by partners and socializing with their network.

Accumulating social capital can be important when other forms of capital are in decline or less valued (Passeron, 1979). Although under the Soviet regime network-based hires played an essential part in labour markets (Böröcz and Southworth, 1998; Völker and Flap, 1999), after transition from socialism to a market economy their role in obtaining jobs became even more crucial (Clarke, 2000; Clarke and Kabalina, 2000; Gerber and Mayorova, 2010; Round et al., 2008; Solodchenko and Sucher, 2005; Yakubovich and Kozina, 2000). As Clarke (2000, p.492) remarks, "In the past, connections were used primarily as a means of getting a better job. Now it is becoming increasingly necessary to have connections to get any job at all."

Furthermore, for employees who carry responsibility for finance, accounting, sales and supplies, strong loyalty to one's employer is highly valued because of widespread illegal practices and paying wages off the books to avoid taxes (Clarke, 2000; Clarke and Kabalina, 2000). In Ukraine, entrepreneurs traditionally search for accountants among friends and relatives irrespective of their qualification over strangers (Solodchenko and Sucher, 2005). In Russia, predominantly small companies are inclined to hire candidates via informal contacts (Gerber and Mayorova, 2010). Another explanation (Ashwin and Yakubovich, 2005) suggests that the introduction of the market economy is accompanied by surging unemployment and steep fall in wages in some industries. The shortage of jobs results in increasing importance of informal networks as they convey information and give access to scare resources whether they are consumer goods prior to the Soviet collapse or jobs afterwards.

Thus, we see that in post-soviet contexts, and perhaps non-Western contexts more broadly, capital conversion processes can take on different forms. For example, institutionalised cultural capital in the form of a professional designation retains its convertibility throughout professional careers in Bangladesh (especially a qualification awarded by the British ICAEW) and Japan (Spence et al., 2015, 2016, 2017b). In Japan, internal social capital that is gradually accumulated through a close and lasting relationship between a candidate as an apprentice and a key senior partner as a patron is most easily convertible into symbolic capital which, in turn, is directly linked to morality - a Big 4 partner as an admirable and worthy individual who will be remembered for raising the next generation of accomplished and honourable partners. In Japan 
patronage is always accompanied by an employee's long-term commitment and loyalty to the firm demonstrated by regular overwork. This commitment constitutes a chronologically-based convertible capital essential to career progression. The maximisation of external social capital represented by building and skilful maintenance of relations through providing clients with excellent service means that in Japan technical expertise takes priority over business development skills and stands in marked contrast to the ideology of commercial capital - selling more non-audit services to the existent clients and building a wide personal network to keep winning new clients - that dominates in countries such as Canada, China, France, Spain and the UK (Spence et al., 2017b). Although in Bangladesh technical excellence in performing rigorous audits (embodied cultural capital) is also favoured over commercial savvy, it assists partners with managing difficult conversations with auditees (external social capital). Technical capital in Bangladesh is therefore essential for building external social capital, whereas internal social capital is often largely inherited because of widespread nepotism and the existence of "accounting dynasties" (ibid.). Ultimately, these types of capital are converted into symbolic capital - service to the national accountancy body and professional community that constitutes Bangladeshi partners' raison d'être (Spence et al., 2016). Overall, this foray into prior literature suggests that capital convertibility processes are not uniform across borders.

\subsection{Research problem}

The review of previous studies clearly shows that we know a great deal about increasing commercialism and the role played by institutionalised and embodied cultural capital both in supporting and hindering the careers of accounting professionals in developed Western countries. However, the majority of prior research privileges a small, elite sub-section of national accounting fields by focusing almost exclusively on Big 4 auditors. Whether or not the rules of successfully navigating around the accounting field are the same for small or mid-size practitioners, or in-house accountants, is unclear. Neither do we know to what extent findings highlighted by prior research are true of the accountancy profession and careers pursued by accounting professionals in emerging economies, especially in post-Soviet countries. This can be particularly relevant to a number of the Baltic States, such as Latvia, which have adopted a neoliberal economic policy model, characterised by working conditions of dubious quality in the post-Soviet period (Woolfson, 2006, 2007). Indeed, the foregoing suggests that the relationship between different forms of capital in countries such as Latvia might not be homologous to how different forms of capital are converted and valued in other contexts. By extension, this implies that professional fields are structured according to different principles in different contexts, in turn demonstrating that there is no essentialised nature of professional groups or professional fields. These conceptual concerns determine the present study's principal research question: What different forms of capital are valued in the Latvian accountancy field by various factions of the accountancy profession? Exploring this question would give us an opportunity to improve our understanding of the contemporary accountancy profession in socioeconomic and political contexts different from Western countries, help explain how professional fields change over time and to chart differences that exist across different segments of the accounting field.

\section{Methods: sample, data collection, analysis 3.1. Research setting}

The accounting system played a crucial role in facilitating market-based reforms in Latvia's economy. As in China (Spence et al., 2017b), upon entering the Latvian audit market shortly after the fall of a centrally planned economy, the Big 4 were also given carte blanche to set "the rules of the game" and to shape the field in their own image. The national government heavily relied on the Big 4 by viewing them as an essential prerequisite for attracting foreign direct investment and as competent consultants on drafting and implementing accounting regulation.

Over the years, the Big 4 have strengthened their leading position in the local market. For instance, in 2020 they audited nine out of 13 banks, five out of six insurance companies founded in Latvia and 345 clients included in the list of TOP 1000 non-financial companies whose net turnover constituted 59\% of 
TOP 1000 total turnover (Andersons, 2021). Although 97 out of 119 audit firms registered in Latvia conducted audits of at least one TOP 1000 company, 64\% of all employees (689 people) worked for the Big 4. In comparison, international non-Big 4 firms (Baker Tilly, BDO, Grant Thornton, Moore, Nexia, PKF, Rödl \& Partner) employed $19 \%$ of the workforce and audited 145 clients that made up only $11 \%$ of the TOP 1000 total net turnover. The average number of employees in local audit firms was just four.

Strong determination to join the EU prompted Latvia to replace its first post-Soviet regulation on certified auditors (1992) with a new law (1995) that was compliant with the requirements of the $8^{\text {th }}$ Council Directive 84/253/EEC. As a result, initial requirements for exam candidates to hold a university degree in accounting and to gain at least five years' experience as an accountant including at least two years' experience in audit under certified auditor's supervision were replaced with a university degree in economic sciences (or other field of studies as long as a candidate has passed an exam in the principles of economics), at least three years' experience in accounting and audit and the threshold age of 25 years. This law also marked the end of a transition period when applicants with a university degree in accounting and at least 10 years of experience in accounting were eligible for sitting professional qualification exams. Since 1996, the law has demanded previous work experience to be gained exclusively in audit; in 2001 a university degree in the field of economics, management or finance became a new mandatory requirement.

According to the State Revenue Service, in Latvia at least $45 \%$ of companies have in-house accountants whereas at least $39 \%$ of companies use outsourced accounting services. The popularity of the latter is constantly increasing and the taxation authority maintains that a significant proportion of these services are in the shadow economy. In 2018, the number of accounting service providers was estimated to be 7400 , including 6000 legal persons and 1400 natural persons whose market share was $89 \%$ and $11 \%$ respectively. The sector predominantly consists of small businesses (just $2 \%$ have annual turnover larger than EUR 150,000) and on average each provider keeps accounting records for approximately 15 clients. For example, $37 \%$ have five or fewer clients whereas $26 \%$ - six to ten clients, $29 \%$ - 11 to 30 clients. For $86 \%$ of natural persons and $62 \%$ of legal persons the number of clients does not exceed seven (Likumprojekta, 2019).

In contrast to the Latvian Association of Certified Auditors whose membership is mandatory for everyone in public practice, accountants are not a regulated profession and cannot achieve complete market closure. Still, in 2017 the law "On accounting" laid down some basic formal competence criteria based on education and/or experience. For example, Level 3 "accountant assistant" is achieved after finishing technical or vocational school, college or training centre whereas Level 4 "accountant" - after finishing college or university college. Alternatively, a candidate's competence in accounting may be evidenced by work experience or an appropriate certificate. Voluntary certification has been carried out by the Latvian Association of Accountants (since 2000 over 600 certificates were issued and about 380 are still valid) and the Centre for Accounting Certification Ltd. (since 2002 over 900 certificates were issued and about 520 are still valid). In 2012, the holders of Centre's certificates established the Association of ISO Certified Accountants which in 2018 was incorporated into the Latvian Association of Accountants. In general, over $80 \%$ of candidates pass certification exams at the first attempt. Despite tremendous efforts, lobbying the government to make certification mandatory was unsuccessful. Similar to accountants, voluntary certification of tax consultants as another unregulated profession is undertaken by the Latvian Association of Tax Consultants (founded in 2001).

\subsection{Data collection}

The empirical material analysed in this paper was obtained from 83 semi-structured in-depth interviews (75 face-to-face and 8 on the phone) conducted as guided conversations (Brinkmann and Kvale, 2015) with accounting professionals in Latvia from June 2015 to September 2016. Although the sample predominantly consists of interviewees who lived or worked in the capital city Riga and its neighbouring regions, participants from other geographical areas gave face-to-face interviews during their business trips or leisure visits to the capital. Initially, interviews were secured using the personal social ties and a subsequent use of a purposive snowballing technique (Patton, 2015).

Apart from few cases, each interviewee gained at least a five-year-long first-hand experience; this length, in authors' opinion, sufficed for building awareness of the tacit "rules of the game" (Bourdieu and Wacquant, 1992) within the field. Table I specifies the profile of interviewees including demographics, 
work experience and qualification. The number of cases in Table I exceeds the number of interviewees because many of them gained experience in several economic sectors and companies both in public practice and industry. For instance, 20 respondents were employed by various international audit firms, including the Big 4, 19 respondents worked for local audit firms while seven respondents had work experience with both international and local audit firms. Whereas at the time of interview six respondents were occupying the positions of chief executives of national professional bodies or had taken them previously, 31 respondents were current or former members on Board Committees of national professional bodies.

The average length of face-to-face interviews was one hour and 16 minutes. The length varied from 20 minutes to three hours and 20 minutes. Phone interviews were about 60 minutes long. 68 face-to-face interviews were audio-recorded and meticulously transcribed verbatim. The interviewer took field notes to ease the recollection of impressions, observations, respondents' reaction and non-verbal communication after interviews (Poland, 1995).

Participants were provided with the broad outline of research topics well in advance of interviews and they were comfortable with sharing their views on several intertwined subjects like their own career progression and trajectories, the significance and a role played by different skills, professional credentials and education, prestige, emolument and the evolution of the profession and the accounting field in rapidly changing political, socioeconomic and cultural environment of the post-Soviet market throughout their careers.

[Insert Table I here]

\subsection{Data analysis}

At a preliminary stage, a native speaker pre-coded the transcription of interviews to spot those fragments that contained rich quotes and the most worthy "codable moments" (Boyatzis, 1998). To employ "concept-driven" (deductive) coding, the authors evolved and rested a primary codebook upon the theoretical framework, extant research, an interview guide and the research question. These basic "etic" codes were non-specific to content and just showed contours of general domains within which "emic" codes were inductively elaborated (Miles et al., 2014). At later stages, the authors reconsidered, adjusted or deleted deductive codes and integrated "data-driven" (inductive) empirically grounded codes for arising themes of interest into the codebook (Brinkmann and Kvale, 2015). A hierarchically structured list of deductive and inductive codes constituted a template to perform a thematic analysis (King, 2004).

The co-authors iteratively went through, examined and discussed more than 600 single-spaced pages of transcripts and field notes until a general consensus about the conceptualization of numerous ideas was achieved. This algorithm promoted the evolution of general categories that the research team jointly pinpointed, discussed, interpreted and elaborated further by narrowing down and condensing into themes and concepts. A recurrent analysis of data within and their juxtaposition across themes, continual revision and distillation enabled the co-authors to preserve internal homogeneity (meaningful coherence within) and external heterogeneity of themes (explicit distinction between) (Patton, 2015). To remedy deficiencies intrinsic to transcripts - "impoverished, decontextualised renderings of live interview conversations" (Brinkmann and Kvale, 2015, p.204) - a native speaker author regularly returned to the audio records to verify the tone of voice, pace of speech, particular stress on specific points, pauses, irony and other turns of phrases that usually are omitted in transcription (Bourdieu et al., 1999, p.622). This accuracy was crucial to deciphering interviewee's meaning that would have remained undisclosed had transcripts alone - "partial accounts of the encounter between researcher and researched" (Poland, 1995, p.306) - been relied upon.

To counter the potential threat of "biased subjectivity" (Brinkmann and Kvale, 2015, p.241) that usually leads to unconscious oversight of counterevidence, the research team aspired to implement "perspectival subjectivity" by challenging developed interrelationships and searching for alternative interpretations of the meaning from different viewpoints. Implementing Brinkmann's and Kvale's (2015) recommendations, preliminary interpretations in the "self-understanding context" investigated situated accounts and situated reality that were "co-created" and socially elaborated by both an interviewer and an interviewee through asking and answering different categories of questions such as the main, follow-up and probing (Dean and 
Whyte, 1970). It was the apprehension of people's experience, outlooks and ambitions (doxa) that rarely appeared as episteme. In the "context of critical common-sense understanding", supplementary interpretations, more investigative and incredulous, crossed individually set boundaries but still did not go beyond the confines of common-sense manifested by objective social structures. Ultimately, in the "theoretical understanding context" the co-authors aimed to decipher the meaning within a theoretical frame. This drift through contexts in a piecemeal fashion manifested transformation from an "experience-near" apprehension created by social actors who in a free-and-easy manner and impromptu portrayed their worlds to the reader's "experience-far" conception employed by researchers to advance a complicated theoretical meaning of phenomenon (Geertz, 1974).

\section{Findings}

\subsection{Institutionalised cultural capital: educational credentials}

An undergraduate degree might be considered "the entry ticket to the field" because the majority of employers require it. One respondent recollected that, shortly after his appointment, a new CEO promised to fire every office worker of a large dairy processing plant unless they submit a university diploma or a certificate of student status. Most respondents strongly believe that the importance of a university degree increases at higher levels of professional hierarchy. There are limited cases when holding a university degree is required by the law. Certified auditors who are obliged to hold a bachelor's degree in Economics, Management or Finance are a typical example. While local audit and accounting service firms and companies prefer applicants with a degree in Accounting or closely related disciplines, the Big 4 firms do not have such preferences because they generally mistrust the quality of Latvian university education and provide each newcomer with obligatory internal training. Compared with accountants, interviewed certified auditors, especially those with a Big 4 background, are much more critical of the quality of university studies in Accounting.

In the late 1990s and early 2000s a postgraduate degree was just introduced in Latvia and perceived as quite an exclusive credential that influenced career trajectories. Since then, the situation has changed dramatically and an increasing number of postgraduates have led to the "inflation of degrees".

Apparently, there is a paradox in Latvia. The majority have higher education but it doesn't make any sense... Approximately 10 years ago we witnessed education boom. And it seems to me there wasn't a single person without a university degree. Maybe just scum and the dregs of society dispensed with it. Everyone was either a lawyer or a manager or an economist. Right now all these economists are picking and packing up mushrooms in the UK. As everyone knows how easy a university degree could be obtained in the past, it would be unusual to receive applications for a vacancy at a middle or upper-middle level from candidates without a degree. [... So, education can't be used as the only selection criterion because higher education can't automatically guarantee that candidates are good specialists. [59: Partner, local audit firm, certified auditor]

Nonetheless, after losing the largest part of their institutionalised value a postgraduate degree still keeps its intrinsic value for many respondents. Many interviewees obtained a master's degree because of a desire for self-development or to boost self-confidence. The exception to this was auditors from the Big 4. In their view, postgraduate studies lack any intrinsic value and are completely irrelevant to practitioners. Although some of these respondents hold a master's degree, they obtained it for purely practical reason such as exemption from conscription or an opportunity to replace onerous ACCA studies with an MBA degree. The results of a comparative analysis of the importance of educational credentials in the accounting field in Latvia are summarised in Table II.

\section{[Insert Table II here]}

Irrespective of the time of graduation most respondents consider their own alma mater as the most prestigious in Latvia. So, the overwhelming majority have earned their undergraduate and postgraduate 
degrees from the same institution. Traditionally, almost all respondents give preference to state higher educational establishments. In comparison with local educational institutions, interviewees consider studies at high-ranking universities in developed Western countries as more prestigious with the exception of Stockholm School of Economics in Riga (SSE hereafter). Respondents with a Big 4 background more frequently expressed willingness to study at a modern, innovative and pro-Western institution with good reputation and to be taught by lecturers from abroad. As many of them are SSE graduates, they particularly favour this school. Many potential employers also view SSE as an efficient recruitment filter. Compared with other educational institutions, a degree earned from SSE is an important indicator of high intellectual potential, perseverance and dedication which are highly appreciated by businesses. However, a number of employers raised important issues.

Actually, SSE has won fame but not good references for its graduates as entry-level employees. [..] they come as winners and claimers immediately upon graduation. In my view, a person without long practical experience should be more realistic and modest. Studies are great stuff but experience is something completely different and more important. SSE does teach students how to present and sell themselves well but I am not sure about anything else. [43: Partner, non-Big 4, certified auditor]

Compared to the situation 10-20 years ago, present day graduates of SSE never start their careers as ordinary accountants or audit assistants even in international companies or audit firms because of their elevated ambitions and aspiration for much more lucrative trajectories. If they join the Big 4 firms, they prefer Consultancy, IT or Corporate Finance departments to Audit.

An auditor is a person who starts from the very bottom of career ladder and works a lot and really hard. In my opinion, SSE instils confidence into graduates that their education gives them the right to take an initial position much higher than auditor's assistant. [..] So, initially these people aren't ready to make a great deal of effort because of holding themselves in great esteem. They need greater challenge; they aren't ready for the growth in audit. It seems too slow to them and they don't want to waste time. [44: Audit director, Big 4, certified auditor, ACCA, CIA, certified tax consultant]

The auditor habitus is seen by SSE graduates as dull, monotonous and inconsistent with their own inherent dynamics. Nonetheless, at present the popularity of the Big 4 firms among SSE graduates and the value of degrees earned from SSE have declined. On the one hand, there are numerous subsidiaries of foreign companies who offer great opportunities for SSE graduates to successfully develop careers. On the other hand, since its establishment in 1994 several thousands of students have already graduated from SSE and their academic credentials have lost exclusivity. Moreover, studies at foreign universities have become more available and popular with the younger generation who actively compete with SSE graduates for better jobs.

\subsection{Institutionalised cultural capital: professional qualifications}

When the national certification of accountants was initially rolled out in the early 2000s, the number of certificate holders was small. The rarity of certificates increased its influence on career trajectories, facilitating pay rises and promotions. In addition, at that point organisations such as the Latvian Association of Accountants and the Centre for Accounting Certification Ltd. were actively lobbying for passing an amendment to the regulation which would give only professionally qualified specialists the right to work as accountants. Although after long and heated debates that lasted for a few years the Ministry of Finance did not support this suggestion, many interviewees have admitted that they obtained certificates in anticipation of new legal requirements.

Over the years, the situation has changed because a gradual spread of certificate and the financial crisis have undermined its importance even in large national and international enterprises where previously it was of some value. Nowadays, almost each unqualified accountant expresses reservation about obtaining this certificate and is convinced that their long experience with accounting fully compensates for its lack. A 
number of certificate holders, frustrated by the low value the labour market places on this credential, consider ceasing it by not applying for re-certification and renewal. At present, experience and knowledge are not seen as guaranteed by the possession of an accounting credential.

Tax consultancy, in contrast to statutory audit and similar to accounting, is not a regulated profession in Latvia. However, a tax consultant certificate might play a positive role at initial stages of a certified auditor's professional career because occasionally some clients pay attention to auditor's credentials. The certificate might retain its importance at later stages of those auditors' career who transcend narrow boundaries of audit and accounting services and position themselves more globally as business consultants, experts and advisors.

Whereas in countries such as Bangladesh the qualification obtained from the Institute of Chartered Accountants of England and Wales (ICAEW) is both widespread and imbued with special symbolic capital (Spence et al., 2016), in Latvia ACCA remains the only popular international credential, possibly because Latvia was never part of the British Empire. While those belonging to the local audit association do not hold it, more than $40 \%$ of interviewed auditors with work experience in any international audit firms are ACCA qualified. The former do not view ACCA studies as a prerequisite of a successful professional career in audit. For the latter, in contrast, ACCA studies are a formative period of becoming a competent specialist and are especially useful during the initial stages of a career. ACCA gained at later stages, e.g., after becoming an experienced holder of local auditor certificate, does not create significant value added in the form of a career boost, either.

Interviewer: Do you prefer the qualification of [local] certified auditor or ACCA?

Respondent: Well, it depends... If we talk about knowledge gained, I definitely and unequivocally prefer ACCA. When I took auditor certification exam, generally I didn't acquire any new knowledge. But this certificate distinguishes me from those who don't have the right to sign off an auditor's report. And I can do business using it. [66: Partner, local audit firm, audit ex-director in Big 4, certified auditor, ACCA, CIA]

In the Big 4 firms, the role of ACCA is even more crucial as it is an obligatory prerequisite for career growth beyond the level of manager. In a number of the Big 4 the requirements are stricter. While managers have to be ACCA qualified, senior managers, directors and partners have to acquire both ACCA and a local auditor's certificate. For example, all the respondents from the Big 4 in our sample hold both certificates. However, the attitude of their younger colleagues towards these requirements has changed.

Nowadays the younger generation is spoiled for choice as there is different work experience and education available. Just few of our employees perceive ACCA studies as a great opportunity for self-development. Actually, there are many people who overappreciate the value of their spare time and numerous options of relaxation. They are not into studying, not into enjoying benefits of it. So, I witness quite a flippant and careless attitude. [48: Leading partner, Big 4, certified auditor, ACCA, certified tax consultant]

Among accountants ACCA is favoured by young specialists with good knowledge of English who are employed by international or large national companies. However, it is difficult to estimate the value of ACCA beyond the audit field. As too many local employers are unaware of it, ACCA qualification is not a decisive factor in getting a prestigious and well-paid job. ACCA is much more appreciated in the companies owned by foreigners, many of whom mistrust the Latvian system of business education. Therefore, ACCA qualification might become important if in the process of selecting candidates a foreign interviewer has more weight.

I'd say that others more acknowledge the fact that I've graduated from the Grammar School No 1. "Wow, you've graduated summa cum laude... Then you must be the right stuff!", they frequently say to me. But they aren't interested in my ACCA certificate at all. So, I don't feel that it's something special either. [56: Partner, local audit firm, ex-manager in Big 4, certified auditor, ACCA] 
Sometimes ACCA becomes an entry ticket to a quite lucrative and closed subfield such as audit of municipalities. In this case, ACCA gets included in the list of obligatory prerequisites of participating in the competition for the audit contracts that are put out to tender. As a result, it reduces the number of potential bidders and outsiders' chances of winning a contest. Table III provides a brief summary of the role and importance of professional qualifications to a successful professional career pursued by various actors in the accounting field in Latvia.

[Insert Table III here]

\subsection{Embodied cultural capital}

Although the majority of interviewed accountants consider certified auditors as constituting a more knowledgeable and prestigious profession, they still prefer to pursue roles as accountants because they view the auditor habitus as too legalistic, formal and mostly involving a search for mistakes. Many accountants, in contrast, perceive themselves as real doers, who "get their hands dirty". Certified auditors, in turn, enjoy constantly changing environment and like a job which provides them with a unique opportunity to broaden professional horizons and see things from completely different perspective, getting access to various companies in a wide range of industries. While they like performing simultaneously the roles of an accountant, psychologist, analyst and auditor, they hate routine and a high level of accuracy that are the essential attributes of any typical accountant's work. In some sense, each group criticises the other for a lack of dynamism and intellectual curiosity.

Universally, a willingness to work hard, keen interest in accounting and audit and continual selfeducation due to rapid changes in tax regulation are essential characteristics of successful specialists working in the accountancy field. Respondents from audit and accounting service firms view excellent communication skills, ability to find a common language and get on really well with any client and other members of the team as particularly important to potential applicants. Traditionally, they must be fluent both in Latvian and Russian. While some knowledge of English is generally an advantage, in firms with international clientele fluency in English might be required. In addition, great significance is attached to sharing the same values and establishing the relationship of unconditional trust. Junior colleagues are expected to be honest and to inform their superiors immediately about any potential problem with their performance instead of concealing information.

Respondents who provide accounting services are particularly valued in the job market. Intimate knowledge of businesses from different sectors, exposure to issues with accounting or taxation in unusual situations such as dissolution of companies develops respondents' competence and flexibility and shows clear evidence of adapting to rapidly changing business environment. Thus, during audit season these respondents are frequently invited to fulfil duties of part-time audit assistants with local or small non-Big 4 international audit firms. Nevertheless, those accountants who have spent long years working for the same company and have been stuck in a groove because of performing just a few narrow accounting operations have a slim chance of finding another job.

I have been auditing this city council for 17 years. Every time I meet the same payroll accountant. I've noticed that over the years even her desk hasn't been moved by $10 \mathrm{~cm}$. She has never moved out of that nook... The only changes I've noticed are a new collection of instructions, a more powerful PC and slightly better accounting software. She sickens of accounting; she isn't into it at all. She has become such a slowcoach... scarcely moves. [..] In my view, it is not normal that an accountant has spent almost two decades sitting in a tiny chamber at the same desk and performing the same daily routine. And then we wonder why they don't show any initiative. They don't give a sh*t, they just want everyone to piss off and leave them alone. [..] And it is typical of almost all my audit clients. [70: Partner, local audit firm, certified auditor, qualified accountant]

The Big 4 firm is the right place for ambitious, highly-motivated, self-confident and curious people with great desire to achieve a lot by learning and working hard long hours in difficult and highly competitive 
environment. Employees come under constant pressure as they have to meet the expectations of this dynamic and extremely demanding system whose core principles are progressing productivity, selfdevelopment and education. Despite exhaustion and burnout, every employee is expected to be the best and brightest to leave no doubt about service quality. If employees lack this strong natural desire for movement forward, they are forced to leave the Big 4 (Table IV).

Vigour must be a distinguishing trait of your character; you should be prepared to tolerate a lot. In my view, it is not the right place for a humane person. I definitely do not belong to people who could stay there for a long time. [59: Partner, local audit firm, certified auditor]

\section{[Insert Table IV here]}

In the Big 4 firms, similar to large companies in industry where multiple levels of accountants' hierarchy exist, the following relationship might be observed. The lower is the level of employees, the more detailed is their technical knowledge, the higher they have climbed, the broader perspective they adopt and more general knowledge they gain. While for managers the key skills are technical, further promotion mostly depends on soft skills - work both internally with the staff and externally with clients that lead ultimately to the accumulation of economic capital.

It is business. We aren't an institution to expect funding from the state. We have to earn every cent. The more we earn, the more we can invest [in business development]. So, it is vital that we attract new clients and offer services that are new to the market. [44: Audit director, Big 4, certified auditor, ACCA, CIA, certified tax consultant]

For partners, selling skills are critically important as they are actively involved in the Big 4 firms' business development.

There are auditors who don't want to make a partner. They might dislike it or be scared of it or just not into selling but you can't be a partner without selling. There isn't a single partner who wouldn't be a salesperson. Those who can't sell, who can't get the client interested in buying services, they doubtlessly can't be partners. [32: Partner, large non-Big 4, certified auditor, ACCA, certified tax consultant]

Instead of leading self-satisfied lives, a feeling of self-motivation constantly pushes audit partners beyond the boundaries of their current comfort zone and drives them and their subordinates forward, to pursue ultimate aims, to introduce new services, to improve the firm's performance.

Actually, if you want to make a partner with the Big 4, you should be a kind of sadomasochist. Because a person who enjoys spending time with their family at home would find doing this sort of job extremely difficult. It is definitely not an 8-9-10-hour job. You are expected to work much more. [56: Partner, local audit firm, ex-manager in Big 4, certified auditor, ACCA]

In local and non-Big 4 international audit firms every partner - certified auditor conducts audits and directly supervises audit assistants. Therefore, instead of focusing exclusively on selling services and developing business like their counterparts in the Big 4, they have to possess the majority of technical and soft skills used by managers and partners. However, a smaller number of subordinates reduce the importance of skills such as leadership and the management of large teams.

A number of local auditors recognize that a small size of audited companies makes the application of the International Standards on Auditing (ISAs) problematic because in most cases an actual audit process becomes similar to stocktaking. Necessity to meet continuously increasing requirements of strict quality control regularly exercised by inspectors of the Latvian Association of Certified Auditors makes local auditors particularly concerned about complying with ISAs and focused on collecting sufficient audit evidence to support their decisions and judgements. Respondents from the Big 4 firms, in contrast, describe an audit process of truly large international companies as "art". 
Actually, they [non-Big 4 auditors] don't quite understand the process. [..] At any of the Big 4 firms audit process is art, it is elaborate and each of steps is contemplated. [..] So, newcomers find it extremely difficult to fit in. And they are much slower because we inculcate high productivity [snapping her fingers quickly] in our employees from the very beginning. Otherwise they would act as a brake at later stages. [..] We used to recruit newcomers in the past but found it inefficient because we had to teach them a lot. Instead, we prefer employing and bringing up the graduates. [48: Leading partner, Big 4, certified auditor, ACCA, certified tax consultant]

In addition to lower work productivity, this difference in attitude to and the comprehension of audit process erects one of the major barriers between local and international auditors. Compared with certified auditors from local and small non-Big 4 international audit firms, the attitude of the Big 4 towards clients is much more formal, pragmatic and structured, focused on commercial aspects by maximizing the effectiveness of auditors' office hours and other resources.

Auditors from local and small non-Big 4 audit firms, in contrast, see themselves generating better value added and are much less focused on selling and accumulating economic capital. In addition, impediments to unlimited growth, clients' continuously rising expectations and increased mobility put the partners under pressure to "render a service of high quality that keeps clients satisfied and interested in cooperating with us next year when we will have an opportunity to offer them other valuable services" [5: Partner, non-Big 4, certified auditor, ACCA, CIA]. Thus, auditors adopt a more flexible and personal approach to clients ("contracts are signed between companies, but it's individuals who work with one another"), willingly go into detail of tax risks and analyze each problem clients face, go the extra mile and keep helping clients with finding the best and most suitable solution also when the audit season is over. If the partners succeed in "proving that client can count on us, confide to us, that we are worth collaborating with" [64: Partner, local audit firm, certified auditor], then "clients enjoy the benefits of audit performed by a knowledgeable professional who becomes their trustful counsellor" [68: Partner, local audit firm, senior ex-manager in Big 4, certified auditor, ACCA]. Auditors gladly act as approachable advisors: provide consultations and answer phone calls even late in the evenings and at weekends. Not surprisingly, the majority of them cannot imagine working for the Big 4 and becoming a small screw in a large perfectly oiled mechanism. Similar to partners in small audit practices, interviewed sole traders and owners of small accounting service firms attach paramount importance to independence, relative freedom to plan their schedules and privilege of not being held accountable to superiors. The psychological portrait of colleagues painted by a partner of a local audit firm implicitly contrasts them with employees in the Big 4 firm where she used to be a senior manager in the early 2000s.

Generally, our employees don't rotate. They are people who feel fully satisfied and comfortable with working in audit, being good doers, having sense of appropriate self-esteem, receiving decent salary. They don't need those steps of career ladders, fetishes, rising from the ranks and so on. Instead of working in that environment, they prefer to breathe more freely and yet remain professionals. [68: Partner, local audit firm, senior ex-manager in Big 4, certified auditor, ACCA]

\subsection{Social capital}

Social capital remains important in the accountancy field in Latvia. Respondents repeatedly talk about the significance of "friend-to-friend" connections (Latvian draugu büšana) and "phoning a friend" (Latvian zvans draugam) to contact "the right people" (Latvian vajadzigie cilvēki; Russian нужные люди [пиzhnуyе lyudi]) in order to become someone's protégé. It is a prerequisite of accessing potential employers such as small audit and accounting service firms and small companies in industry. These businesses pay much more attention to recommendations given by friends, neighbours or former colleagues than to a potential candidate's formal education and training, certificates, previous workplaces or responsibilities. It is believed that a social network likewise plays the key role in landing highly lucrative jobs in state- and municipalityowned enterprises.

According to respondents, their operational social network has been built up gradually starting from childhood and school. Childhood friends, school and university group mates of several local certified 
auditors constituted the largest proportion of their initial portfolio upon starting audit practice. Being a semiprofessional athlete in her youth assisted one auditor with spotting clients even among her former teammates. The same is true for those providing accounting services. We found several examples of highly efficient networks developed in the Big 4 and non-Big 4 international firms that help interviewees with finding jobs in industry. In one case, unfamiliar parties who worked for a large non-Big 4 German accounting firm at different points in time found one another through a very long chain of current and former colleagues. Aided by this chain of connections, one of these individuals became a chief accountant of an international luxury hotel.

In practice, clients regularly ask local certified auditors to recommend them "a good accountant". Although employers' needs presumably differ widely, our analysis shows that who you know is seemingly more important than what you can do. As no one ever specifies what this "goodness" means to them, these words become a secret code that replaces a long list of the required and desirable skills a suitable candidate must possess.

However, the usefulness of social connections goes far beyond finding a job or clients. In the early 1990s, an alumni network let one of our respondents contact "the right people" who allowed her to join the group of prospective National Audit Office's employees, undergo prohibitively costly professional training offered by the official centre of learning free of charge and, consequently, pass certified auditors' qualification exams. Similarly, a close friendship with accounting academics in the University of Latvia enabled other four interviewees to attend a two-year long training course run by a Latvian expatriate who held a top management position in the Big 4 in Sweden and arrived in Riga to set up a local branch. The interviewees viewed the course as the turning point in their lives: it helped them in joining the Big 4 firm, passing qualification exams and opening their own audit practices at a later stage of their careers.

According to some respondents, the importance of a social network might be attributed to a special position taken by accountants in most companies. Unlike other occupations in the private sector, an accountant should be "a trustworthy person" the owner and managers can rely on because even insignificant mistakes in accounting or taxation could result in severe penalties. A social network is also virtually indispensable for finding accountants who would "solve the problem by adopting prohibited methods" [18: Partner, acc. services, qualified accountant] such as creative accounting leading to tax evasion.

Whereas a secretary would find a job in private sector without using a social network, an accountant would not. So, the fact that many accountants do not pursue their profession just means the lack of required social connections. [34: sole trader, accounting services]

Respondents admit that using a social network does not always lead to a positive result and is a lottery because some candidates might turn out to be even worse employees than any outsider. Nevertheless, it does not deter most employers from looking for candidates exclusively through social connections. Though the right social connections do not automatically guarantee immediate employment, in most cases they considerably improve the candidate's chances of getting invited for interview in the field of accounting and audit. Occasionally not offering a job to a protégé or finding out later that an employee does not live up to a promise might worsen a social relationship between an employer and a proposer.

The rule of social connections has some exceptions, particularly in the Big 4 where candidate selection is based on credentials. However, the situation was different in the 1990s when the Big 4 first offices were established in Riga. At that point in time, we were told that being bosom friends or close acquaintances of employees in the Big 4 was "the entry ticket" to this highly prestigious, lucrative and closed field and significantly improved the chance of getting invited for a job interview.

At that point of time I worked as an accountant. For personal reasons, I wanted to change my job and started asking my acquaintances whether there was an opportunity to take the position of audit assistant with the Big 4. None of them could help me. Somehow, I missed this opportunity because at that time this kind of jobs was available just through friends or acquaintances. [4: Partner, local audit and acc. service firm, certified auditor, certified tax consultant] 
Since the 1990s, it would appear that the Big 4 have implemented global HR standards more seriously. Another challenge to dense webs of local relationships is posed by foreign enterprises as newcomers to the Latvian market that do not belong to any social network. Therefore, they are not exposed to word-of-mouth information and are forced to rely on something else such as candidates' credentials.

Using a social network is particularly important to those employees whose competitiveness is lower due to advanced age or the lack of relevant work experience. All the cases when a job is found without using social network have common features: either it is poorly paid and work environment is unfavourable or the search takes several months. However, there are numerous interviewees who have never been hired through direct applications despite long work experience, necessary skills and relevant education.

All those advertised vacancies... You know, I really do want to emphasize that sometimes they seem to be advertised as just a formality, nothing else. They launch a competition because they should. But the winners are already known. [19: Accountant, acc. services, qualified accountant]

Most respondents from small and medium-sized businesses believe in objective selection of candidates for high-level positions in large companies when credentials play a vital role. Nonetheless, our respondents from large enterprises speak from experience and debunk this myth by arguing that social connections also significantly improve a chance of employment or promotion in large companies.

I don't believe that nowadays you can find a good job without favouritism even though you hold all the necessary certificates, diplomas and degrees. I know that and I've talked to other people as well: social network counts both at a lower and higher level. It permeates entire hierarchy because there is a severe shortage of jobs. [..] But those without knowledge and qualifications need jobs too and they also want to do well in life. So, they intensively use social networks. [..] Although competitions are launched and vacancies advertised, patronage is widespread. As a result, all candidates are equal but some candidates are more equal than others [49: Chief accountant, large local company, unqualified]

Traditionally, social network also plays the important role of the channel through which professional knowledge is disseminated because discussing problematic and vaguely regulated cases in taxation or financial reporting is common and widespread practice within accountants' community. Regular attendance of training courses or seminars and membership of professional associations facilitate establishing and maintaining these social relations. Sometimes it might produce spectacular results. A local certified auditor recollects how making friends with "the right people" while going to seminars organised by a British nonBig 4 international accounting firm, getting involved in a joint project and putting forward "an elegant solution to an extremely unpleasant problem" led to an immediate offer to join the firm as an audit director. Despite general consensus on the significance of social capital in the accountancy field in Latvia, most our respondents admit that they should invest much more resources into its acquisition and maintenance.

\section{Discussion and conclusions}

This exploratory study enriches our knowledge of the influence of less developed socioeconomic and political contexts on the structure and development of professional fields. Specifically, the aim of the present research was to investigate what different forms of capital are valued in the Latvian accountancy field by various factions of the accountancy profession. The results of the analysis of this study have raised a number of interesting issues and revealed the dynamic nature and changes in the significance of various types of capital over the years following the collapse of the planned economy. Overall, in addition to empirically charting the contours of the Latvian accountancy field for the first time, we make three broad conceptual contributions to the study of professional fields. Firstly, we illustrate how different sections of the field privilege certain forms of capital over others, highlighting field heterogeneity and spatial differentiation. Not only does this replacement of connections with credentials demonstrate fluctuating capital values, it also indicates different values accorded to different forms of capital by different groups of actors in the field 
contemporaneously. In short, it demonstrates field heterogeneity. While extant research has explored professional accounting fields in capitalist countries (e.g., Canada, France, Japan, Spain and the United Kingdom) and large developing economies (e.g., a former British colony Bangladesh and post-communist China) through the prism of the Big 4 (e.g., Boussebaa, 2015; Lupu and Empson, 2015; Spence and Carter, 2014; Spence et al., 2015, 2016, 2017a, 2017b), our findings go beyond this particular perspective and provide valuable insights into different forms of capital valued differentially across the entire professional accounting field.

Secondly, we show how forms of capital come to have different values attached to them over time, highlighting a temporal dimension to professional field structure. Financial and symbolic benefits from the educational credentials greatly depend on their scarcity. "Credential inflation" (Collins, 2011) might make investments in education considerably less profitable (Bourdieu, 1986) due to an increasing number of graduates who compete with each other in the job market. Holding a degree is no longer sufficient for finding a job because the devaluation of educational credentials propels employers to impose stricter requirements and raise entry standards (Collins, 2011) - a process of devaluation that has been taking place in Latvia. While at present holding an undergraduate degree is taken for granted and, therefore, required for getting access to the accountancy field, a postgraduate degree has stopped performing the role of career driving force in the late nineties and early 2000s when it was a rare and exclusive credential. Similarly, a broad spread of national accounting qualifications has undermined the major positive influence on career trajectories which they had upon their introduction. Nevertheless, their transformation from institutionalised into embodied cultural capital has enabled a postgraduate degree and national qualifications to retain intrinsic value that boosts candidate's self-confidence and strengthen personal belief into their own capability and intelligence.

Nowadays, to excel among competitors and get a job, in addition to an undergraduate degree (institutionalised cultural capital) and personal contacts that help to overcome "the closure of labour market" and get access to a potential employer (social capital), a successful job applicant in the Latvian accountancy field is required to know several languages (linguistic capital), have long work experience as all-round accountant or audit assistant, demonstrate industry, good communication skills, evince a keen interest in the profession, share the same values with a potential employer and show an ability of establishing a relationship of unconditional trust between himself as a subordinate and his superiors (embodied capital). In other words, over the years a gradual devaluation of institutionalised cultural capital (an undergraduate degree) has led to a steady rise in the prominence of other types of capital (e.g., linguistic and embodied) and the right type of habitus which operates as an amplifier of the efficiency of job applicants' educational (institutionalised cultural) capital (Bourdieu, 1984, p.143; Jacobs, 2003) and social capital. Although in general social capital plays a crucial role in finding a job in the Latvian accounting field, considerable stabilization of the institutional presence of the Big 4 in Latvia has allowed them to replace a social network widely used in recruitment in the years following the restoration of independence with the merit-based selection mechanism typical of other countries.

Finally, we highlight not only how different forms of capital fluctuate in value across time and space but the field itself can become less desirable to certain holders of capital, prompting them to seek entry to adjacent or different fields entirely.

Historically, we could draw a parallel between SSE in Riga and the grandes écoles in France educational institutions that are highly prestigious due to a strict selection of applicants and testify to graduates' conferment of degrees, characteristics such as leadership, intellectual brightness and belonging to an exclusive "old-boy network". However, recently a number of important differences have emerged. For example, if grandes écoles still remain one of the main sources of workforce supply for the audit department of the Big 4 in France, over recent years the situation in Latvia has changed. Nowadays, both the Big 4 in general and their audit departments in particular have lost popularity among the SSE graduates. Although the Big 4 audit recruiters still favour SSE students, the latter prefer corporate finance, IT and consultancy departments of the Big 4 and other large national and international companies. In this respect, it is not capital that is becoming less valuable in the field so much as the field becoming less desirable to holders of certain forms of capital.

Although we did not dedicate a separate section in the findings to economic capital, this was because economic capital in a commercial field such as accounting is somewhat transversal, offering a litmus test or 
barometer against which to measure other forms of capital in many respects. Considering economic capital considerations here in conclusion allows us to infer other forms of heterogeneity in the field. Traditionally, the importance of effective selling is less pronounced in small local and non-Big 4 international audit firms. These firms have limited growth capacity because of the presence of just one or two certified auditors, a small number of audit assistants, and a lack of audit project managers. Much better remuneration and international professional qualifications such as ACCA held by partners in the Big 4 denote greater economic and institutionalized cultural capital compared with their small and mid-size counterparts. Nevertheless, while partners in the Big 4 are mostly involved in developing new business, partners in small local and non-Big 4 international audit firms are more heavily involved in conducting audits and supervising audit assistants. Therefore, we can draw a conclusion about fundamental differences in the composition and the amount of capital possessed by partners in different segments of the Latvian audit market. In turn, this demonstrates the heterogeneity of the Latvian accounting field and of professional fields more broadly.

While there is no distinction between the convertibility of various types of capital and considering economic capital as the "crown jewel" in the Big 4 across western countries and Latvia, there are peculiar kinds of association in other segments of the Latvian field. As small and medium-sized employers expect any accounting work to be done by a "trustworthy person", possessing the right external social capital (a social network) to land a job and accumulating internal social capital (the building and maintenance of an extremely close and long-term relationship with a superior) are combined with technical excellence to become someone who is dubbed "the good accountant" (symbolic capital). However, in practice, what constitutes "good" here heavily depends on the context. For example, occasionally particular technical knowledge such as the development of tax avoidance schemes and readiness to use such knowledge might be a necessary precondition for "goodness".

Limited capacity for indefinite growth and relatively high mobility of clients typically make the partners of small non-Big 4 as well as local audit and accounting firms concerned about their retention by offering clients services of excellent quality (the mix of technical expertise and external social capital). Their continuous satisfaction also becomes an essential prerequisite for selling them additional services that can add value to their business (commercial capital). Although the accumulation of economic capital prima facie might be interpreted as the ultimate goal of these partners, it seems to be a beneficial side effect of the major focus on serving clients' needs.

The empirical findings of this study relate to a small post-Soviet transition economy, Latvia, that is just one of numerous former members of the Communist Bloc whose national economies, population levels, standards of living and cultural particularities vary considerably. As such, we do not know to what extent these results are generalizable. Future research could fruitfully interrogate how relevant they are to similar contexts and other developing countries. Furthermore, although we observe spatial and temporal differences in the values attached to different forms of capital, our data was undertaken in a relatively short time period of 15 months. As such, it was easier to discern spatial than temporal differences. While we are confident in being able to identify the latter, future studies adopting longer data collection periods or drawing on a longue durée range of historical documents would be well placed to draw more concrete inferences as to how capital values fluctuate over time. In terms of future conceptual development, whether capital values fluctuate across time and space because of field-specific changes, societal wide changes or both was difficult to comprehensively discern from the data collected by the present study, even if some plausible reflections have been offered. Future research in Latvia and other contexts could seek to disentangle these drivers in an attempt to more fully understand the underlying drivers for field-level change. Such work would be relevant for not just accounting scholars but scholars of fields more broadly.

\section{References}

Adler, P.S. and Kwon, S.W. (2002), "Social capital: prospects for a new concept", Academy of Management Review, Vol. 27 No. 1, pp.17-40. https://doi.org/10.5465/amr.2002.5922314

Ahadiat, N. and Martin, R.M. (2016), "Necessary attributes, preparations, and skills for the selection and promotion of accounting professionals", Journal of Accounting and Finance, Vol. 16 No. 1, pp.11-25. 
Alam, A., Murthi, M., Yemtsov, R., Murrugarra, E., Dudwick, N., Hamilton, E. and Tiongson, E. (2005), Growth, Poverty and Inequality. Eastern Europe and the Former Soviet Union, World Bank, Washington. https://doi.org/10.1596/978-0-8213-6193-1

Albu, C.N., Albu, N., Faff, R. and Hodgson, A. (2011), "Accounting competencies and the changing role of accountants in emerging economies: the case of Romania", Accounting in Europe, Vol. 8 No. 2, pp.155-184. https://doi.org/10.1080/17449480.2011.621395

Alexander, D. and Ghedrovici, O. (2013), "Evolution of accounting in Moldova: some reflections about the importance of historical and cultural factors", Albu, C.N. and Mustata, R.V. (Ed.s), Research in Accounting in Emerging Economies, Accounting in Central and Eastern Europe, Vol. 13, pp.121-142. https://doi.org/10.1108/s1479-3563(2013)0000013010

Almăşan, A. and Grosu, C. (2008) "Managers' awareness of the accounting information usefulness", Journal of Accounting and Management Information Systems, Vol. 24, pp.57-71.

Anandarajan, A., Hasan, I., Moyes, G. and Wulsin, F. (2002), "Gender, ethnicity, and demographic factors influencing promotions to managers for auditors: an empirical analysis", Lehman, C.R. (Ed.), Advances in Public Interest Accounting, Mirrors and Prisms: Interrogating Accounting, Vol. 9, pp.1-29. https://doi.org/10.1016/s1041-7060(02)09004-1

Anderson-Gough, F., Grey, C. and Robson, K. (2005), ““"Helping them to forget..”: the organizational embedding of gender relations in public audit firms", Accounting, Organizations and Society, Vol. 30 No. 5, pp.469-490. https://doi.org/10.1016/j.aos.2004.05.003

Anderson-Gough, F., Grey, C. and Robson, K. (2006), "Professionals, networking and the networked professional", Greenwood, R. and Suddaby, R. (Ed.s), Research in the Sociology of the Organizations, Professional Service Firms, Vol. 24, JAI Press, Greenwich, pp.231-256. https://doi.org/10.1016/s0733$558 \mathrm{x}(06) 24009-6$

Andersons, U. (2021), "Lielais četrinieks turpina dominēt", available at: https://forbesbaltics.com/lv/reitingi/raksts/lielais-cetrinieks-turpina-dominet (accessed 30 August 2021)

Anheier, H.K., Gerhards, J. and Romo, F.P. (1995), "Forms of capital and social structure in cultural fields: examining Bourdieu's social topography", American Journal of Sociology, Vol. 100 No. 4, pp.859903. https://doi.org/10.1086/230603

Annisette, M. (2000), "Imperialism and the professions: the education and certification of accountants in Trinidad and Tobago", Accounting, Organizations and Society, Vol. 25 No. 7, pp.631-659. https://doi.org/10.1016/s0361-3682(99)00061-6

Ashwin, S. and Yakubovich, V. (2005), "Chercher la Femme: women as supporting actors in the Russian labor market", European Sociological Review, Vol. 21 No. 2, pp.149-164. https://doi.org/10.1093/esr/jci010

Baysden, C. (2014), "How to speed the path to partner", Journal of Accountancy, Vol. 217 No. 3, pp.28-32.

Bhamornsiri, S. and Guinn R.E. (1991), "The road to partnership in the "Big Six" firms: implications for accounting education", Issues in Accounting Education, Vol. 6 No. 1, pp.9-24.

Bourdieu, P. (1977), Outline of a Theory of Practice, Cambridge University Press, Cambridge.

Bourdieu, P. (1984), Distinction: A Social Critique of the Judgement of Taste, Routledge, London.

Bourdieu, P. (1986), "The forms of capital", Halsey, A.H. (Ed.), Education: Culture, Economy, and Society, Oxford University Press, New York, pp.46-58.

Bourdieu, P. (1990), In Other Words: Essays towards a Reflexive Sociology, Stanford University Press, Stanford.

Bourdieu, P. and Wacquant, L.J.D. (1992), An Invitation to Reflexive Sociology, University of Chicago Press, Chicago.

Bourdieu, P., Accardo, A. and Ferguson, P.P. (1999), The Weight of the World. Social Suffering in Contemporary Society, Stanford University Press, Stanford.

Boussebaa, M. (2015), "Professional service firms, globalisation and the new imperialism", Accounting, Auditing \& Accountability Journal, Vol. 28 No. 8, pp. 1217-1233. https://doi.org/10.1108/aaaj03-2015-1986

Boyatzis, R. (1998), Transforming Qualitative Information: Thematic Analysis and Code Development, Sage Publications, London. 
Böröcz, J. and Southworth, C. (1998), “'Who you know': earnings effects of formal and informal social network resources under late state socialism in Hungary, 1986-87", Journal of Socio-economics, Vol. 27, pp.401-425. https://doi.org/10.1016/s1053-5357(99)80096-1

Brink, A.G., Norman, C.S. and Wier, B. (2016), "Attained education and promotion in public accounting", Issues in Accounting Education, Vol. 31 No. 3, pp.301-320. https://doi.org/10.2308/iace51244

Brinkmann, S. and Kvale, S. (2015), InterViews. Learning the Craft of Qualitative Research Interviewing, Sage, London.

Clarke, S. (2000), "The closure of the Russian labour market", European Societies, Vol. 2 No. 4, pp.483-504. https://doi.org/10.1080/713766999

Clarke, S. and Kabalina, V. (2000), "The new private sector in the Russian labour market", EuropeAsia Studies, Vol. 52 No. 1, pp.7-32. https://doi.org/10.1080/09668130098244

Collins, R. (2011), "Credential inflation and the future of universities", Italian Journal of Sociology of Education, Vol. 2, pp.228-251.

Cooper, D.J., Greenwood, R., Hinings, B. and Brown, J.L. (1998), "Globalization and nationalism in a multinational accounting firm: the case of opening new markets in Eastern Europe", Accounting, Organizations and Society, Vol. 23 No. 5-6, pp.531-548. https://doi.org/10.1016/s0361-3682(98)00026-9

Dean, J.P. and Whyte, W.F. (1970), "What kind of truth do you get? How do you know if the informant is telling the truth?", Dexter, L.A. (Ed.), Elite and specialized interviewing, Northwestern University Press, Evanston, pp.119-138.

Dobbin, F. (2008), "The poverty of organizational theory: comment on Bourdieu and organizational analysis", Theory and Society, Vol. 37 No. 1, pp.53-63. https://doi.org/10.1007/s11186-007-9051-z

Dyball, M.C., Poullaos, C. and Chua, W.F. (2007), "Accounting and empire: professionalization-asresistance - the case of the Philippines", Critical Perspectives on Accounting, Vol. 18 No. 4, pp.415-449. https://doi.org/10.1016/j.cpa.2006.01.008

Faulconbridge, J.R. and Muzio, D. (2012), "Professions in a globalizing world: towards a transnational sociology of the professions", International Sociology, Vol. 27 No. 1, pp.136-152. https://doi.org/10.1177/0268580911423059

Geertz, C. (1974), "“From the native's point of view": on the nature of anthropological understanding", Bulletin of the American Academy of Arts and Sciences, Vol. 28 No. 1, pp.26-45. https://doi.org/10.2307/3822971

Gerber, T.P. and Mayorova, O. (2010), "Getting personal: networks and stratification in the Russian labor market, 1985-2001", American Journal of Sociology, Vol. 116 No. 3, pp.855-908. https://doi.org/10.1086/655750

Gillis, P., Petty, R. and Suddaby, R. (2014), "The transnational regulation of accounting: insights, gaps and an agenda for future research", Accounting, Auditing \& Accountability Journal, Vol. 27 No. 6, pp.894902. https://doi.org/10.1108/aaaj-07-2014-1757

Grabinski, K., Kedzior, M. and Krasodomska, J. (2014), "The Polish accounting system and IFRS implementation process in the view of empirical research", Journal Accounting and Management Information Systems, Vol. 13 No. 2, pp.281-310.

Grey, C. (1998), "On being a professional in a "Big Six" firm", Accounting, Organizations and Society, Vol. 23 No. 5/6, pp.569-587. https://doi.org/10.1016/s0361-3682(97)00003-2

Grosu, C., Almăşan, A. and Circa, C. (2014) "The current status of management accounting in Romania: The accountants' perception", Accounting and Management Information Systems, Vol. 13 No. 3, pp.537-558.

Guinn, R.E., Bhamornsiri, S. and Blanthorne, C. (2004), "Promotion to partners in big firms: truths and trends", The CPA Journal, Vol. 74 No. 4, pp.54-55.

Hall, P. and Soskice, D. (2001), "An introduction to the varieties of capitalism", Hall, P. and Soskice, D. (Ed.s), Varieties of Capitalism: The Institutional Basis of Competitive Advantage, Oxford University Press, Oxford, pp.1-70. https://doi.org/10.1093/0199247757.003.0001

Hartmann, M. (2000), "Class-specific habitus and the social reproduction of the business elite in Germany and France", Sociological Review, Vol. 48 No. 2, pp.262-282. https://doi.org/10.1111/1467954x.00214 
Haynes, K. (2012), "Body beautiful? Gender, identity and the body in professional service firms", Gender, Work and Organization, Vol. 19 No. 5, pp.489-507. https://doi.org/10.1111/j.14680432.2011.00583.x

Heyns, B. (2005), "Emerging inequalities in Central and Eastern Europe", Annual Review of Sociology, Vol. 31, pp.163-197. https://doi.org/10.1146/annurev.soc.30.012703.110637

Jacobs, K. (2003), "Class reproduction in professional recruitment: examining the accounting profession”, Critical Perspectives on Accounting, Vol. 14, pp.569-596. https://doi.org/10.1016/s10452354(02)00140-5

Johnson, L.M. and Johnson, V.E. (1995), "Help wanted- accountant: what the classifieds say about employers' expectations", Journal of Education for Business, Vol. 70 No. 3, pp.130-134. https://doi.org/10.1080/08832323.1995.10117738

Johnson, T.J. (1973), "Imperialism and the professions: notes on the development of professional occupations in Britain's colonies and the New States", Sociological Review, Vol. 20 No. 1, pp.281-309. https://doi.org/10.1111/j.1467-954x.1972.tb03222.x

Kallaste, K. and Alver, J. (2017), "The recertification of the professional accounting qualification in Estonia. The requirements and quality of CPD”, Zeszyty Teoretyczne Rachunkowości, Vol. 93 No. 149, pp.113-134.

King, N. (2004), "Using templates in the thematic analysis of text", Cassell, C. and Symon, G. (Ed.s), Essential Guide to Qualitative Methods in Organizational Research, Sage Publications, London, pp.256270. https://doi.org/10.4135/9781446280119.n21

Kornberger, M., Justesen, L. and Mouritsen, J. (2011), "When you make manager, we put a big mountain in front of you': an ethnography of managers in a Big 4 accounting firm", Accounting, Organizations and Society, Vol. 36 No. 8, pp.514-533. https://doi.org/10.1016/j.aos.2011.07.007

Ledeneva, A. (1998), Russia's economy of favours: Blat, networking and informal exchange, Cambridge University Press, Cambridge.

Likumprojekta "Grozījumi likumā "Par grāmatvedību"” sākotnējās ietekmes novērtējuma ziņojums (anotācija) (2019), available at:

https://titania.saeima.lv/LIVS13/saeimalivs13.nsf/0/37398152B625B4FAC225850A00505893?OpenDocu ment (accessed 30 August 2021)

Lupu, I. and Empson, L. (2015), "Illusio and overwork: playing the game in the accounting field", Accounting, Auditing \& Accountability Journal, Vol. 28 No. 8, pp.1310-1340. https://doi.org/10.1108/aaaj02-2015-1984

Maclean, M., Harvey, C. and Kling, G. (2015), "Business elites and the field of power in France", Elites on Trial. Research in the Sociology of Organizations, Vol. 43, pp.189-219. https://doi.org/10.1108/s0733-558x20150000043019

Malsch, B., Gendron, Y. and Grazzini, F. (2011), "Investigating interdisciplinary translations. The influence of Pierre Bourdieu on accounting literature", Accounting, Auditing \& Accountability Journal, Vol. 24 No. 2, pp.194-228. https://doi.org/10.1108/09513571111100681

Margheim, L., Hora, J.A. and Pattison, D. (2010), "Educational competencies that mid-sized CPA firms value in their professional accounting staff", American Journal of Business Education, Vol. 3 No. 6, pp.6980. https://doi.org/10.19030/ajbe.v3i6.444

McGee, R.W. (Ed.) (2008), Accounting Reform in Transition and Developing Economies, Springer, New York. https://doi.org/10.1007/b135906

Mennicken, A. (2008), "Connecting worlds: the translation of international auditing standards into post-Soviet audit practice", Accounting, Organizations and Society, Vol. 33 No. 4, pp.384-414. https://doi.org/10.1016/j.aos.2007.06.001

Mennicken, A. (2010), "From inspection to auditing: audit and markets as linked ecologies", Accounting, Organizations and Society, Vol. 35 No. 3, pp.334-359. https://doi.org/10.1016/j.aos.2009.07.007

Michailova, S. (1993), "Contrasts in culture: Russian and western perspectives on organizational change", The Academy of Management Executive, Vol. 14 No. 4, pp.99-112. https://doi.org/10.5465/ame.2000.3979819 
Miles, M.B., Huberman, A. M. and Saldaña, J. (2014), Qualitative Data Analysis. A Method Soursebook, Saga, London.

Morgan, G., Campbell, J., Crouch, C., Pedersen, O. and Whitley, R. (2010), The Oxford Handbook of Comparative Institutional Analysis, Oxford University Press, Oxford. https://doi.org/10.1093/oxfordhb/9780199233762.001.0001

Mueller, F., Carter, C. and Ross-Smith, A. (2011), "Making sense of career in a Big Four accounting firm", Current Sociology, Vol. 59 No. 4, pp.551-567. https://doi.org/10.1177/0011392111402734

Passeron, J.C. (1979), "Democratization of higher education in Europe: a retrospective view", Prospects, Vol. 9 No. 1, pp.43-53. https://doi.org/10.1007/bf02220498

Patton, M.Q. (2015), Qualitative Research \& Evaluation Methods: Integrating Theory and Practice, Sage, London.

Poland, B.D. (1995), "Transcription quality as an aspect of rigor in qualitative research", Qualitative Inquiry, Vol. 1 No. 3, pp.290-310. https://doi.org/10.1177/107780049500100302

Rivera, L.A. (2011), "Ivies, extracurriculars, and exclusion: elite employers' use of educational credentials", Research in Social Stratification and Mobility, Vol. 29, pp.71-90. https://doi.org/10.1016/j.rssm.2010.12.001

Rivera, L.A. (2012), "Hiring as cultural matching: the case of elite professional service firms", American Sociological Review, Vol. 77 No. 6, pp.999-1022. https://doi.org/10.1177/0003122412463213

Round, J., Williams, C.C. and Rodgers, P. (2008), "Corruption in the post-Soviet workplace: the experiences of recent graduates in contemporary Ukraine", Work, Employment and Society, Vol. 22 No. 1, pp.149-166. https://doi.org/10.1177/0950017007087421

Ryan, G.W. and Bernard, H.R. (2003), "Techniques to identify themes", Field Methods, Vol. 15 No. 1, pp.85-109. https://doi.org/10.1177/1525822x02239569

Samsonova-Taddei, A. (2013), "Social relations and the differential local impact of global standards: the case of International Standards on Auditing", Abacus, Vol. 49 No. 4, pp.506-538. https://doi.org/10.1111/abac.12017

Seal, W., Sucher, P. and Zelenka, I. (1996), "Post-socialist transition and the development of an accountancy profession in the Czech Republic", Critical Perspectives on Accounting, Vol. 7 No. 4, pp.485508. https://doi.org/10.1006/cpac.1996.0048

Sian, S. (2006), "Inclusion, exclusion and control: the case of the Kenyan accounting professionalisation project”, Accounting, Organizations and Society, Vol. 31 No. 3, pp.295-322. https://doi.org/10.1016/j.aos.2005.01.004

Sikka, P. (2008), "Enterprise culture and accountancy firms: new masters of the universe", Accounting, Auditing \& Accountability Journal, Vol. 21 No. 2, pp.268-295. https://doi.org/10.1108/09513570810854437

Shlapentokh, V. (1996), "Early feudalism. The best parallel for contemporary Russia", Europe-Asia Studies, Vol. 48 No. 3, pp.393-411. https://doi.org/10.1080/09668139608412355

Solodchenko, I. and Sucher, P. (2005), "Accounting in Ukraine since independence: real politik, problems and prospects", European Accounting Review, Vol. 14 No. 3, pp.603-633. https://doi.org/10.1080/0963818042000336755

Spence, C. and Carter, C. (2014), "An exploration of the professional habitus in the Big 4 accounting firms", Work, Employment and Society, Vol. 28 No. 6, pp.946-962. https://doi.org/10.1177/0950017013510762

Spence, C., Carter, C., Belal, A., Husillos, J., Dambrin, C. and Archel, P. (2016), "Tracking habitus across a transnational professional field", Work, Employment and Society, Vol. 30 No. 1, pp.3-20. https://doi.org/10.1177/0950017015574824

Spence, C., Carter, C., Husillos, J. and Archel, P. (2017a), “Taste matters: cultural capital and elites in proximate Strategic Action Fields", Human Relations, Vol. 70 No. 2, pp.211-236. https://doi.org/10.1177/0018726716649247

Spence, C., Dambrin, C., Carter, C., Husillos, J. and Archel, P. (2015), “Global ends, local means: cross-national homogeneity in professional service firms", Human Relations, Vol. 68 No. 5, pp.765-788. https://doi.org/10.1177/0018726714541489 
Spence, C., Zhu, J., Endo, T. and Matsubara, S. (2017b), "Money, honour and duty: global professional service firms in comparative perspective", Accounting, Organizations and Society, Vol. 62, pp.82-97. https://doi.org/10.1016/j.aos.2017.09.001

Sturges, J., Simpson, R. and Altman, Y. (2003), "Capitalising on learning: an exploration of the MBA as a vehicle for developing career competencies", International Journal of Training and Development, Vol. 7 No. 1, pp.53-66. https://doi.org/10.1111/1468-2419.00170

Sucher, P. and Bychkova, S. (2001), "Auditor independence in economies in transition: A study of Russia", European Accounting Review, Vol. 10 No. 4, pp.817-841.

Suddaby, R., Cooper, D.J. and Greenwood, R. (2007), "Transnational regulation of professional services: governance dynamics or field level organizational change", Accounting, Organizations and Society, Vol. 32 No. 4/5, pp.333-362. https://doi.org/10.1016/j.aos.2006.08.002

Tobór-Osadnik, K., Wyganowska, M. and Kabalski, P. (2013) "International Financial Reporting Standards vs. homo sovieticus personality - the case of Poland", International Journal of Business and Social Research, Vol. 3 No. 6, pp.17-35.

Völker, B. and Flap, H. (1999), "Getting ahead in the GDR. Social capital and status attainment under communism”, Acta Sociologica, Vol. 42 No. 1, pp.17-34. https://doi.org/10.1080/00016999950079925

Wacquant, L.J.D. (1996), "Reading Bourdieu's capital", International Journal of Contemporary Sociology, Vol. 33 No. 2, pp.151-170.

Woolfson, C. (2006), "Working environment and 'soft law' in the post-communist new Member states”, Journal of Common Market Studies, Vol. 44 No. 1, pp.195-215. https://doi.org/10.1111/j.14685965.2006.00619.x

Woolfson, C. (2007), "Pushing the envelope: the 'informalization' of labour in post-communist new EU Member states", Work, Employment and Society, Vol. 21 No. 3, pp.551-564. https://doi.org/10.1177/0950017007080016

Yakubovich, V. and Kozina, I. (2000), "The changing significance of ties. An exploration of the hiring channels in the Russian transitional labor market", International Sociology, Vol. 15 No. 3, pp.479-500. https://doi.org/10.1177/026858000015003003

Zarzycka, E. (2017), "The role of management accountant in enterprises operating in Poland", Zeszyty Teoretyczne Rachunkowości, Vol. 93 No. 149, pp.235-252.

Zinoviev, A. and Janson, C. (1982), Homo Sovieticus, Atlantic Monthly Press, Boston. 
Table I. General profile of interviewees

\begin{tabular}{|c|c|c|c|c|c|c|}
\hline Gender & \multicolumn{3}{|c|}{70 FEMALE interviewees } & \multicolumn{3}{|c|}{13 MALE interviewees } \\
\hline Age & \multicolumn{3}{|c|}{$\begin{array}{l}\text { Min } 26 \text { years, max } 86 \text { years } \\
\text { Mean } 48 \text { years, median } 50 \text { years } \\
\text { SD } 14 \text { years }\end{array}$} & \multicolumn{3}{|c|}{$\begin{array}{l}\text { Min } 24 \text { years, max } 52 \text { years } \\
\text { Mean } 47 \text { years, median } 37 \text { years } \\
\text { SD } 14 \text { years }\end{array}$} \\
\hline Relevant work experience & \multicolumn{3}{|c|}{$\begin{array}{l}\text { Min } 2.5 \text { years, max } 65 \text { years } \\
\text { Mean } 21 \text { years, median } 21 \text { years } \\
\text { SD } 9 \text { years }\end{array}$} & \multicolumn{3}{|c|}{$\begin{array}{l}\text { Min } 1 \text { year, max } 26 \text { years } \\
\text { Mean } 15 \text { years, median } 15 \text { years } \\
\text { SD } 6 \text { years }\end{array}$} \\
\hline \multicolumn{7}{|c|}{ Respondents' highest positions taken in each type of company, if any, throughout their careers } \\
\hline Public practice & \multicolumn{2}{|l|}{ 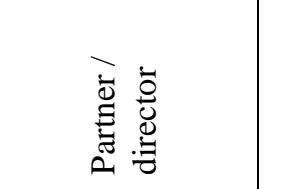 } & 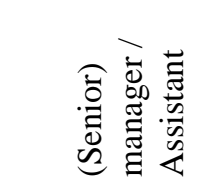 & 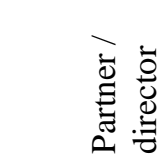 & \multicolumn{2}{|r|}{ 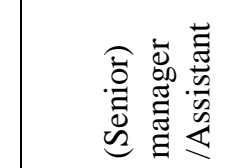 } \\
\hline Big 4 & \multicolumn{2}{|l|}{$2 / 2$} & $4 / 1$ & $2 /-$ & \multicolumn{2}{|r|}{$3 / 1$} \\
\hline Non-Big4 & \multirow{2}{*}{$\frac{21-}{5 /-}$} & \multicolumn{2}{|r|}{$3 /-$} & $2 / 1$ & \multicolumn{2}{|r|}{$-1-$} \\
\hline Local firms & & \multicolumn{2}{|r|}{$-/ 2$} & $2 /-$ & \multicolumn{2}{|r|}{$-1-$} \\
\hline Industry & 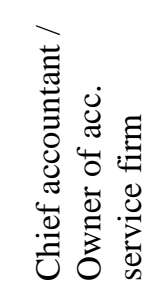 & 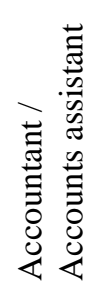 & 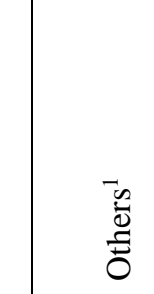 & 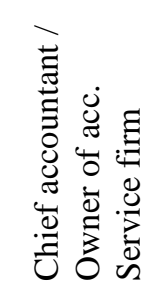 & 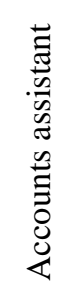 & 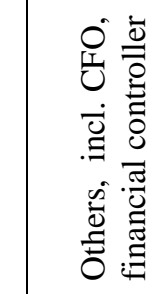 \\
\hline \multicolumn{7}{|l|}{ Accounting services } \\
\hline$\sim$ as a sole trader & \multicolumn{3}{|c|}{5} & \multicolumn{3}{|c|}{-} \\
\hline$\sim$ as a firm & $-/ 6$ & $9 /-$ & - & $-/ 2$ & 1 & - \\
\hline National company & $12 /-$ & $4 /-$ & 3 & $4 /-$ & - & 1 \\
\hline Branch of international company & $5 /-$ & $1 /-$ & 1 & $2 /-$ & - & 2 \\
\hline $\begin{array}{l}\text { Top-5 sector leaders by company } \\
\text { size }\end{array}$ & $12 /-$ & $5 / 1$ & 1 & $2 /-$ & - & 2 \\
\hline \multicolumn{7}{|c|}{ Qualification } \\
\hline Certified auditor (incl. ACCA) & \multicolumn{3}{|c|}{$23(6)$} & \multicolumn{3}{|c|}{$5(3)$} \\
\hline Certified tax consultant & \multicolumn{3}{|c|}{7} & \multicolumn{3}{|c|}{2} \\
\hline CIA & \multicolumn{3}{|c|}{3} & \multicolumn{3}{|c|}{-} \\
\hline Certified accountant ${ }^{2}$ & \multicolumn{3}{|c|}{15} & \multirow{2}{*}{\multicolumn{3}{|c|}{6}} \\
\hline Others $^{3}$ & \multicolumn{3}{|c|}{8} & & & \\
\hline
\end{tabular}

${ }^{1} \mathrm{CFO}$, financial controller, internal auditor, accounting software analyst, accounting certification official

${ }^{2}$ The Latvian Association of Accountants and the Association of ISO Certified Accountants

${ }^{3}$ ACCA-DiplFR, Institute of Professional Financial Managers, International Association of Bookkeepers 
Table II. The role of institutionalised cultural capital: educational credentials

\begin{tabular}{|c|c|c|c|c|}
\hline \multirow{2}{*}{\multicolumn{2}{|c|}{ Actors }} & \multicolumn{2}{|c|}{$\begin{array}{l}\text { Degree in Accounting } \\
\text { or related subject }\end{array}$} & \multirow{2}{*}{ Comments } \\
\hline & & Undergraduate & Postgraduate & \\
\hline \multirow{3}{*}{ 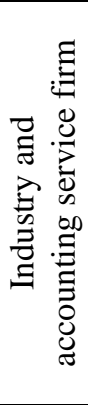 } & $\begin{array}{l}\text { Accountant } \\
\text { in small company or acc. } \\
\text { service firm }\end{array}$ & Desirable & Not important & $\begin{array}{c}\text { Long relevant work } \\
\text { experience as } \\
\text { substitute for UG }\end{array}$ \\
\hline & $\begin{array}{l}\text { Accountant } \\
\text { in medium-large company } \\
\text { or acc. service firm }\end{array}$ & Important & $\begin{array}{l}\text { Might be an } \\
\text { advantage in a } \\
\text { large company }\end{array}$ & $\begin{array}{l}\text { Long relevant work } \\
\text { experience might } \\
\text { compensate for UG in } \\
\text { irrelevant subject }\end{array}$ \\
\hline & $\begin{array}{l}\text { Accountant of narrow } \\
\text { specialisation }\end{array}$ & Important & Not important & $\begin{array}{l}\text { Technical school } \\
\text { qualification might } \\
\text { suffice } \\
\end{array}$ \\
\hline \multirow{3}{*}{ 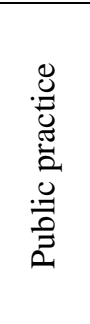 } & Certified auditor & Required by law & Not important & \\
\hline & $\begin{array}{l}\text { Audit assistant in local or } \\
\text { non-Big } 4 \text { international } \\
\text { audit firm }\end{array}$ & Important & $\begin{array}{l}\text { Might be an } \\
\text { advantage }\end{array}$ & $\begin{array}{l}\text { Long relevant work } \\
\text { experience might } \\
\text { substitute for UG or } \\
\text { UG in irrelevant } \\
\text { subject }\end{array}$ \\
\hline & $\begin{array}{l}\text { Audit assistant in the Big } 4 \\
\text { firm }\end{array}$ & Very important & Not important & $\begin{array}{l}\text { Subject does not } \\
\text { matter }\end{array}$ \\
\hline
\end{tabular}


Table III. The role of institutionalised cultural capital: professional qualifications

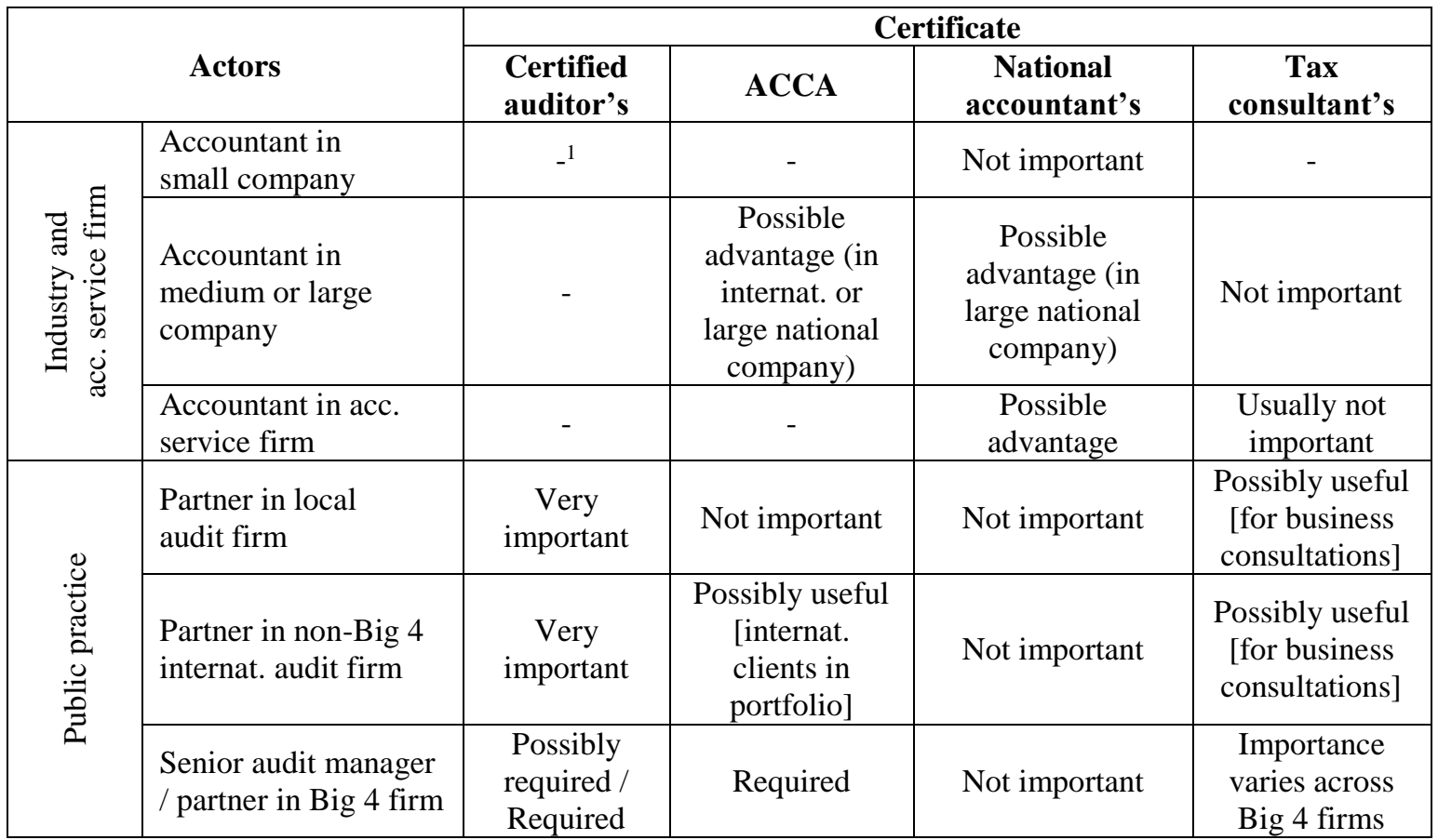

1 ‘_‘ unusual place of work or inappropriate position for a certificate holder 
Table IV. A comparison of embodied cultural capital of successful candidates for the accounting and audit assistant's positions

\begin{tabular}{|c|c|c|}
\hline Industry and accounting service firm & $\begin{array}{c}\text { Local audit firm } \\
\text { and small non-Big 4 }\end{array}$ & $\begin{array}{c}\text { The Big 4 and } \\
\text { large non-Big 4 }\end{array}$ \\
\hline Knowledge of languages & $\begin{array}{c}\text { Local company: fluency in LV, RU. } \\
\text { Good ENG is advantage. } \\
\begin{array}{c}\text { Internat. company: fluency in LV, RU, } \\
\text { ENG }\end{array}\end{array} \begin{array}{c}\text { Fluency in LV, RU } \\
\text { To be conversant in } \\
\text { ENG might be required }\end{array}$ & Fluency in LV, RU, ENG \\
\hline Relevant previous work experience & Required & $\begin{array}{c}\text { Large non-Big 4: required } \\
\text { [with some exceptions] }\end{array}$ \\
\hline $\begin{array}{c}\text { All-round accountant: required } \\
\text { Acc. of narrow specialisation: desirable } \\
\text { Acc. assistant: advantage }\end{array}$ & Extremely important & $\begin{array}{c}\text { The acceptance of firm's } \\
\text { culture is important }\end{array}$ \\
\hline Direct match and trust between superior and inferior & Extremely important \\
\hline \multicolumn{2}{|c|}{ Extremely important } & Very important \\
\hline Capacity for work under stress conditions for long overtime hours \\
\hline \multicolumn{2}{|c|}{ Less important } & $\begin{array}{c}\text { Big 4: extremely important } \\
\text { Large non-Big 4: } \\
\text { important }\end{array}$ \\
\hline High level of ambitions and self-confidence
\end{tabular}

